\title{
TESHIJSAR DOTES
}

\section{Simple Tool for Collecting}

\section{Indian Ricegrass Seed}

\section{W. RICHARD MCDONALD, MURLE P. HAFNER, AND DELWIN L. RICHARDS, JR.}

Highlight: A tool for collecting seeds of Indian ricegrass and other native species has been made by the Federal Bureau of Mínes. With this hand-held seed collector, one person can collect enough material to produce 3 to 5 pounds of clean Indian ricegrass seed per day. Cleaning the seed takes only $1 / 3$ of the time traditionally required because $90 \%$ of the stalks are left on the plants.

The Federal Bureau of Mines has been researching the stabilization of mineral wastes and other disturbed lands since 1967. Techniques in short-term chemical stabilization, permanent vegetative stabilization, and a combination of the two have been demonstrated across the United States. Many of these areas are so highly stressed that only a few plant species can survive. Since Indian ricegrass (Oryzopsis hymenoides) is often found growing near demonstration plots, it is a natural choice for revegctation; however, in the past, seed gathering and cleaning have been difficult, tedious, and costly. A typical method for seed collecting and cleaning involves handrubbing to break the seed away from the chaff, screening to remove the large pieces of chaff, and air separation to remove the remaining chaff from the seed.

The Federal Bureau of Mines' Salt Lake City Metallurgy Research Center has built a seed collector that greatly simplifies harvesting and cleaning seeds of Indian ricegrass and other native species. With this hand-held seed collector, one person can

Authors are metallurgist and physical science technicians, Salt Lake City Metallurgy Research Center. Bureau of Mines, U.S. Department of the Interior, Salt Lake City, Utah. gather enough material to produce 3 to 5 pounds of clean Indian ricegrass seed per day. In addition, $90 \%$ of the stalks are left on the plants so that seed cleaning requires only hand-rubbing, screening, and air separation which takes only $1 / 3$ of the time traditionally required.

The seed collector, which weighs only $3 / 4$ pound, is shown in Figure 1. The materials for construction are a 1-gallon plastic bottle reinforced with 20-gauge aluminum, a metal pet comb, and a plastic quart jar with metal ring. As shown in Figure 1, the 1-gallon bottle is cut down and the pet comb is attached to make the leading edge. The seeds are combined from the plant into the 1-gallon bottle as shown in Figure 2. The 1-quart bottle serves as a storage bin.

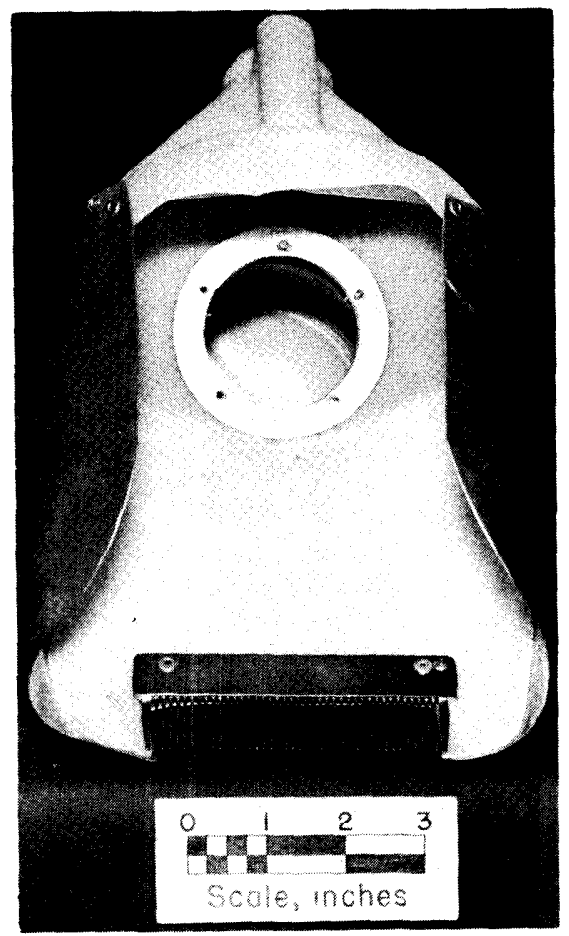

Fig. 1. Top view of seed collector.

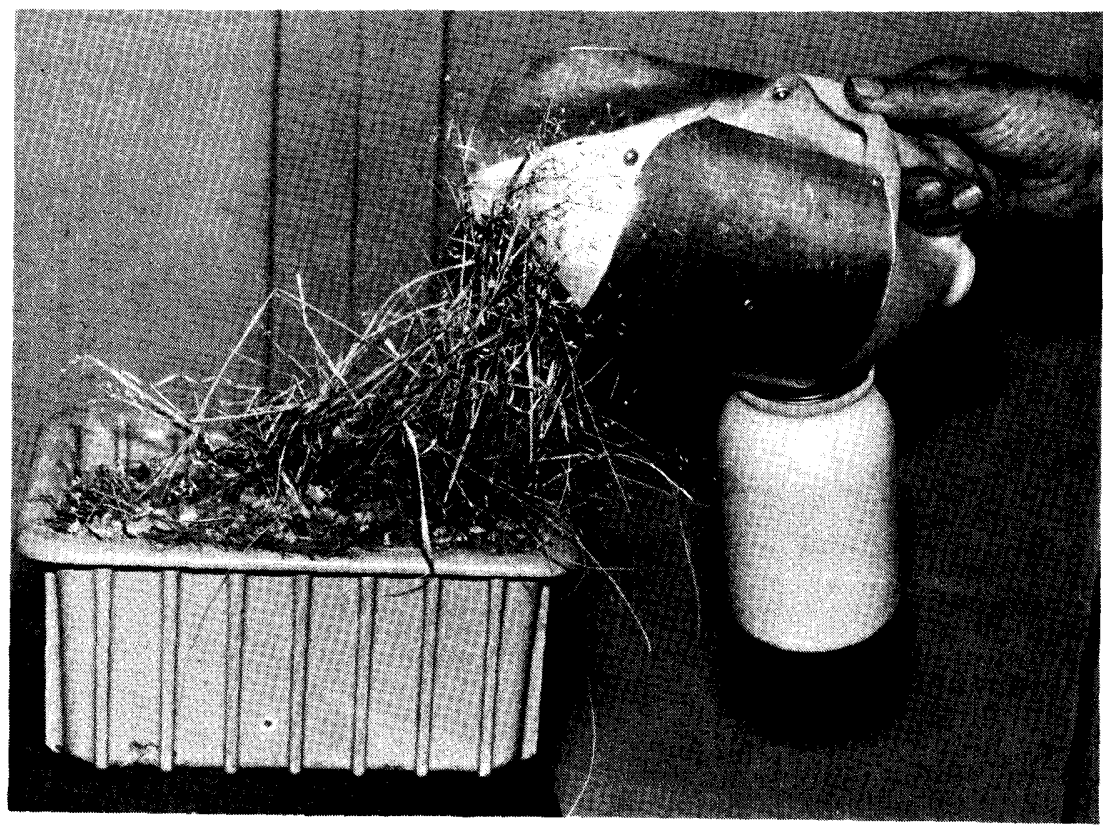

Fig. 2. Simulated gathering of Indian ricegrass seed. 